\title{
Democratize Health Policy Through Citizen's Charter in North Bengkulu District
}

\section{Achmad Aminudin ${ }^{1}$}

\begin{abstract}
This research is analyzing about how the policy of democratization and regional autonomy can born Citizen's Charter in public sevice. The purpose of the regional autonomy implementation is to shortening the distance of service among goverment and the society, so the local goverment can understand more about desires, aspirations and needs of the community compared with the central government who has longer distance from the society. The effort to shortening the distance makes the execution of regional autonomy needs some changes and inovations in giving the service in order to match with the society needs. The result of this research shows that the democratization and regional autonomy policy still can't born the Citizen's Charter in local public service yet, particularly in health care services contract in the Arga Makmur city, North Bengkulu. Realization of the Citizen's Charter principles in the Puskesmas Arga Makmur, North Bengkulu district is proved to have different characteristics with the Citizen's Charter which occurred in Java commonly. In North Bengkulu, the implementation of the Citizen's Charter not only need strong political will from local goverment, budget support (General Revenue and Expenditure Budget/ APBD), the availability of adequate infrastructure, commitment and quality of the resource officers, community support, the importance of shifting paradigm in society toward formal treatment like Puskesmas, but also need a personal leadership for the head of Puskesmas. Without any initiation from personal leadership, it can be sure that the implementation of Citizen's Charter in regional seems can't be running well.
\end{abstract}

\section{Keywords:}

democratization; regional autonomy; public services and citizen's charter

\section{Introduction}

Public Services is an important issue that need more study, because it is related to government's role in providing services to its citizens. Public Service is a direct government's role in order to fulfill people's needs by giving a good, fast, safe, easy, cheap and accountable service, especially in the region. So, the government has made a public service to be a main target for implementation of the democratization and regional autonomy policy.
Democratization policy in service and the execution of regional autonomy hopefully can create a Citizen's Charter to optimalize the service. Solution to optimalize public service need some changes by using an adoption and innovation programs. One of the forms innovation in public service is the application of Citizen's Charter.

The theme of public services has become an interesting topic that the author struggled, especially since political reform and reform of

\footnotetext{
${ }^{1}$ Bengkulu University

Email: achmad.aminudin.unib@gmail.com
} 
the bureaucracy being intensively conducted in Indonesia. Since 2008 until today along with the rapid globalization and development of public administration in which the New Public Service as an advanced paradigm lot followed by governments in many developed countries and developing countries, not to mention the Republic of Indonesia. Issuance of Law No. 25/ 2009 on Public Service and Regulation of Its Implementation, does not necessarily succeeded in improving the performance of public services provided to the public. People who constantly encourage democratization and decentralization today are not getting a balanced response from the government to improve fundamental change aspects of public service improvements.

Many phenomena of increasing public services with the opening of the Office of Integrated Licensing Services, One Stop Service Office, and so on are not automatically show the increasing of public services performance. Realized indeed, the public bureaucracy during this activity they tend only intended to achieve objectives efficiently, effectively and economically (3E) not to touch on the application of the principles of public service that is responsive, representative, and responsible (3R), non-discriminatory, and accountable. Therefore, with the implementation of the Citizen's Charter as a form of execution paradigm of the New Public Service in the public service, to be interesting and urgent to do research empirically.

With the democratization policy in the service and execution of regional autonomy was expected to lessen the gap of service between the government and the community, so that the government area is more understand a desire, aspirations, and needs of the people than with the central government that has a distance away from society.

The effort to shortening the distance of service makes the execution of regional autonomy needs some changes and inovations in giving the service in order to match with the society needs and modern goverment. This is in line with the spirit of Indonesian Statue No. 32/2004 on Regional Government in Local Government which is the chief executive of regional autonomy community that is required to be able to provide better services to improve prosperity in a democratic society.

The empiric reality showed that democratic governance was born to serve its citizens. The Duties of the government is to find ways to please its citizens. This commitment can only be held if people feel that the government still lead to protect and serve the community. In practice of democracy, a leading indicator of implementation democracy is in public service because democracy as a concept can only be felt by the quality of service that provided by the government to its people. In this context, public services become an important tool to see democracy and decentralization. So that democracy and decentralization has to be seen from the ability of the government and local government in doing the real social transaction in the daily life that is public services.

Based on Law No. 25/2009 on Public Service in article 1, the meaning of public services is an activity or a series of activities in order to meet the needs services suitable with rules and laws for every citizen upon goods, services, and administrative services provided by the organizer public services. Public services in fact is the fulfillment of the primary needs as a civil rights of every citizen. In the effort to fulfill basic needs, so that the government is asked to be able to provide service that is expected as according to the 1945 Constitution. Thus public services in Indonesia is a constitutional rights that must be fulfilled by every citizen.

But, in fact public services which are good, fast, safe, easy cheap, and accountable until now is still becoming a dream by society. People who are constantly promote democratization and decentralization has yet to receive response from the government to make improvements in 
public services. While quality of public services often used as an indicator good public services in Indonesia.

Sedarmayanti (2009) illustrate a public services in Indonesia is still having 1) Discrimination of service: differentiation in treatment by service providers based on social and economic status users, 2) Uncertainty service: uncertainty procedures, time and cost service, 3) Levels of satisfaction community to public service is not yet satisfying. Based on survei by Center of Population and Policy Studies (CPPS) Universitas Gadjah Mada in 2007, it prove that the public services in the regency/city in Indonesia is still full of uncertainty costs, time and services. This is because there are no service procedures like obligation by service provider and the right from the community as users. Procedure is likely to be set up only an obligation residents when faced with the regime service. This uncertainty is likely to be encouraged people to pay bribes, to the official so the services can be obtained. As a result, bribery and illegal tariffs is a phenomenon that is more widely accepted and is considered to be normal. Furthermore uncertainty, another problem that is often found in the service is discrimination service based on relationship friendships in the community. So procedures that determined is not to facilitate but to control the bahavior, and there are still overlapping authority service of bureaucracy. This condition is a signals to need for a solution to improve quality and service performance, beside a high level of commitment from all stakeholders element holding public services. Another factor that also are suspected to be the cause bad public service performance is complicated bureaucratic structures of public services (Dwiyanto, 2010).

Along with that, the impact development has led to raise awareness in all sectors of the community so there is a shift in the form of way of thinking and acting that affecting all dynamics sectors and on the life of the people.
One of the shift of thinking is the requirement how providing high quality in public services, compliance with the values and the need for community (Subijanto, 2007).

Bureaucracy in public services often do not have the adequate authority to complete the public services in his working unit; There are three important issues that need to addressed in the public service (Maani, 2005), which are : First, the amount discrimination service. Second, there is no certainty costs, time and the procedure service. Third, the low levels of satisfaction society against the public service. Low quality public services are then leads to cases that are classified as maladministration. For example of mal-administrative service, the treatment are unjust, demand rewards, and abuse. In general conditions in the drawing on poor three aspects, which are management, human resources, and institutional public services in Indonesia which covers (Syukri, 2010, p. 45).

1. The pattern of implementation is less responsive, less informative, less accessible, less than coordination, too Bureaucratic, will not hear, and inefisien;

2. Human resources less professional, competent, empathy, and ethically.

3. Institutional tend to Petitioners failed submit and are not designed to be able to provide services to the society in an efficient and optimum.

Others forms that show a bad face in public services are orientation of service is to the government interests and officials, even often make the public disappointed. Not a few people who are still often feel compounded when dealing with bureaucracy, except that if they were willing to provide and pay more money. Different with the slogan and promises that convey. With conditions like this, conventional management services that ignore the community participation in implementation process service will not be 
maintained. Community involvement in the public services will be able to guarantee the public services to be accountable and able to fulfill their aspirations community service .

In fact the community is the party that most know about what they need to do so. As user services they not only understand what is needed but also how its quality. Thus, the community must be given an involved space for not only in the creation but also in determining standard services that they want. Because of that community participation in the process, and service management must be immediately opened (Denhardt \& Denhardt, 2003). In this case people should be given the opportunity to express their own interests in the management and the government or the providers must make public interests as main criteria in organizing the public service.

New approaches to involve citizens and stakeholders in the public service has been done through the information service or contract service. Administrative Reform (Menpan) adopted a citizen's charter by developing information service, which is set up a promise from the organizer to users about how service will be held. As a promise, the information was made by the organizer by involving the users. The contract service is the agreement between bureaucracy service and the community users and also the people who have an interest about the service that will be given, time, the fees and how the implementation will be. So, the contract service is a new breakthrough in the event public services that more participatory and to empower the community.

Good practice or even best practice procedures of Citizen's Charter can be observed (Wahyudi, 2009) in Bogor for example with Citizen's Charter was succeeded in increasing effectiveness service in the population division. At the City of Mataram, West Nusa Tenggara, contract service will significantly succeeded in increasing quality of service in waste handling through mediation between provider and user services. A contract modification service has been done by Purworejo District Central Java by using e-government, to support Health Information System (SIK) per sub-district in Purworejo.

Drafting and implementation process of Citizen's Charter in public services are in accordance with a paradigm NPS using the main principles, which are: participatory, transparency and accountability. In every process of the preparation, planning, formulating and drawing up a policy always put the togetherness and will be done by involving all stakeholders.

This research examines health policy implementation that carried out a health clinic in North Bengkulu District. A Health Clinic goal in this research is focused on a health clinic Perumnas City Arga Makmur North Bengkulu district which is already carry out some health service to the community that indicate based on the principles of the agreement, better known as Citizen's Charter. Because this program so interesting, it has already had many awards, especially from the North Bengkulu district, the Governor, and even from the Minister of Health, Republic of Indonesia. So, these questions are going to be answered is whether's democratization service and regional autonomy has brought and created a formula of Citizen's Charter in public services in North Bengkulu District or not?

\section{Literature Review}

A Paradigm that most up-to-date amenities in public services according to Denhardt \& Denhardt is New Public Services (NPS). Paradigm public services, has through many changes from a shift to shift. Denhardt \& Denhardt (2003; 2007) divided State Administration Science development in three major paradigm that are Old Public Administration (OPA), New Public Management (NPM), and New Public Service (NPS), that can be seen in the table 1.

In general the way of thinking in NPS paradigms against previous (1. Old Public 
Table 1.

Paradigm Shift in Public Services

\begin{tabular}{|c|c|c|c|}
\hline Aspect & $\begin{array}{c}\text { Old Public } \\
\text { Administration }\end{array}$ & $\begin{array}{c}\text { New Public } \\
\text { Management }\end{array}$ & New Public Service \\
\hline $\begin{array}{l}\text { The Basic theoretical and } \\
\text { The foundation epistimologi }\end{array}$ & Political theory & Economic theory & Democratic theory \\
\hline $\begin{array}{l}\text { The concept } \\
\text { Public interest }\end{array}$ & $\begin{array}{l}\text { Public interest } \\
\text { Politically explained and } \\
\text { expressed in the rule of } \\
\text { law }\end{array}$ & $\begin{array}{l}\text { Public interest } \\
\text { Represents interests of the } \\
\text { individual aggregation may } \\
\text { happen }\end{array}$ & $\begin{array}{l}\text { Public interest } \\
\text { Is the result dialog values }\end{array}$ \\
\hline $\begin{array}{l}\text { Responsivitas } \\
\text { Bureaucracy public }\end{array}$ & Clients and, Instituted on & Customer & Citizen's \\
\hline The role of government & Rowing & Steering & Serving \\
\hline Accountability & $\begin{array}{l}\text { Hierarchy } \\
\text { Administrative level } \\
\text { stressed }\end{array}$ & $\begin{array}{l}\text { Work according to } \\
\text { The market }\end{array}$ & $\begin{array}{l}\text { Multi aspects: } \\
\text { Accountability law, and } \\
\text { values, } \\
\text { The community, norma } \\
\text { politics, professional } \\
\text { standard }\end{array}$ \\
\hline Organization structure & $\begin{array}{l}\text { The other bureaucratic } \\
\text { Marked with the } \\
\text { authority top-down }\end{array}$ & $\begin{array}{l}\text { Decentralization } \\
\text { organization that main } \\
\text { controls is at the agents }\end{array}$ & $\begin{array}{l}\text { Collaborative structure } \\
\text { With a share ownership in } \\
\text { internal and external }\end{array}$ \\
\hline $\begin{array}{l}\text { The assumption of } \\
\text { Motivation governors and } \\
\text { administrator }\end{array}$ & $\begin{array}{l}\text { Wages and } \\
\text { Profits, protection }\end{array}$ & $\begin{array}{l}\text { Entrepreneur } \\
\text { spirit }\end{array}$ & $\begin{array}{l}\text { Public Service } \\
\text { With a desire to serve the } \\
\text { community }\end{array}$ \\
\hline
\end{tabular}

Source: adapted from Denhardt and Denhardt (2003, pp. 28-29)

Adiministration (OPA), 2. New Public Management (NPM). Theoretical basis paradigm NPS was developed from theories about democracy, with more respect differences and human rights, participation citizens.

The relation between paradigm change with the Citizen's charter is in changing public service of bureaucracy response from those third paradigm that is a focus on service Old Public Administration to constituents (voters) and client shift to costumer (violations in New Public Management, and from costumer shift to citizen's to paradigm New Public Service.

NPS concept in public interest is dialog values among the community. The values such as justice, transparency and accountability are values that praise in public services. Paradigm of NPS view the responsivitas (responsibility) bureaucracy more directed to the citizen's not clients, constituents and is not customer. The Government is asked to see that society as a citizen that pay taxes. In a country that embraced understand democracy, in fact citizens not only be viewed as customer that need to be treated with certain standards, but more than that, they are the owner of government that provide services (Dwiyanto, 2005).

De Vries (1995) illustrates that there are several characteristics of public services that have a stake in the public interest. First, community groups are considered work partners (partners). Secondly, the role of the government is not aimed at providing services, becoming a mediator of conflict, or controlling the community, but rather on how to define the role itself in its relations with other institutions in society. Third, the model of governance (governance). To realize the characteristics of the first public service, there are several indicators that must be fulfilled, namely: (1) the nature of the procedure. In this case, the procedure is agreements that can be negotiated and are self-regulation; (2) the nature of information. Policy information is not a means of control of government institutions, but is a tool for the birth of mutual understanding among the institutions involved; (3) the nature 
of the consultation. The consultation process is not solely intended to expect feedback from involved actors, but rather on how to create a win-win solution; (4) institutional patterns, partnerships between public institutions and private institutions in a broad sense.

The second feature requires that government institutions do not advance the power approach in relation to community groups. The government institution should ideally not dwell on the issue of institutional status that emphasizes political legitimacy but rather the actualization of roles that are capable of sowing practices of involvement in community groups in clean and authoritative governance processes. The third feature is the form of governance. Governance is a concept that refers to the problem of how to run the government in a broad sense. In governance, government institutions play an important role because they are the only actors who have political legitimacy. Despite being a key player, government institutions do not dominate the administration of the wheels of government. The share of community groups outside the government is very coloring the process of organizing service functions. In addition to the active involvement of community groups, the wheels of governance are run based on the principles of transparency, accountability and participation. Therefore, in the context of fulfilling the needs and interests of the public in this service, of course, how public matters really are put together as a problem, no longer a problem which is then claimed from one party, but multi parties, both state and private, civil society. Likewise with the process of fulfilling community rights to service, of course the principles of transparency, accountability and participatory are key variables to be implemented. These three building principles of governance, cannot be run individually, there is a very close relationship (De Vries, 1995).

Public Service by bureaucracy public is one of the manifestations of the state as a public servant community in addition as a public servant country. Public Service by bureaucracy public is intended to make the people (welfare citizens) from a welfare state. Public Service by the State Administration (1998) is defined as all forms of activity in public services that carried out by Central Government, in the region and the environment for State-Owned Enterprises in the shape/Region and/or good service in order to fulfill the needs of the society When implementing a law and regulations. Public Services that can be interpreted as a giving services (serve) person or community that has interest to the organization in accordance with the principal and procedures that have been set.

From many literature review in the begining, it is mentioned that bureaucracy public played an important role in the conduct of the administration process as well as Regional Government. Either good or bad the conduct of the administration and public service is determined by the quality bureaucracy in a country. In theory and practice, bureaucracy, has through various changes, and the development. Logical consequences from the development of bureaucracy is shifting in service paradigm.

Paradigm shift was also caused the implications for the role of bureaucracy, especially in relation to an approach that is used in the making strategies, management organization internally; and the interaction between bureaucracy with politicians, and the community and other actors. The implications in the end it was very determined by variety in the event of governance in a country, including Indonesia. Those Style and various were determined by local conditions or community, which is how far bureaucracy in countries have been adapt to the development of paradigm.

A New Public Service started its point of view by having a confession upon its citizen and its position that has very important part for democratic governance. Citizens do not only be viewed as merely a personal interest (self-interest) but also involved, belief, values 
and a concern for other people. The citizen is positioned as the owner of government and be able to act together to achieve something better. Public interests will no longer be regarded as agregation of personal interests but as a result of dialog and engagement public in searching for common values and common interests. A New Public Service want the administrator public to involve the community in the government and it is assigned to serving the community.

In brief, perspective New Public Service can be seen from several principles put forward by Denhardt \& Denhardt (1992). The principles are among others: 1 . Serve citizens, not customer. This principle assumes that people were citizens not customers, because there is no owner in the goverment process. In essence community is the legal owner of it is the country itself. 2. Seek public interest, this principle to give priority to public interest is not private. 3. Citizenship over entrepreneurship, this principle Preferring to make it more respect for the public than entrepreneurship. 4. Recognize that a Citizen's Charter accountability not simple, in this perspective society servant should be more concerned than market mechanism. In addition, society servant also had to obey rules and regulation as well as societal values, norms, political, and the public interests.

Charter is generally defined as a written document delivered by the sovereign or legislature. A citizen's charter is a microconcept in the sense that it is invoked by an organization. Secondly, it is as a rule, proclaimed by an organization having its day-to-day dealings and contacts with citizens. These organizations could be local governments, subordinate offices of the government, banking and financial institutions, public utilities etc. Thirdly, all these organizations promise rendering of services to the citizens within a specified time-frame and conforming to a certain standard. One aspect of citizen's charter is particularly noteworthy. The sanction behind the citizen's charter is moral and nothing else. The proclaiming agency makes it absolutely explicit that it is not justifiable: a citizen cannot sue an organization for not abiding by its selfproclaimed standards of services embodied in a citizen's charter. The charter may thus be seen as only emphasizing the moral dimension of civil service accountability (Stone, 1995, p. 520).

As part of the world citizen, public administration principle in Indonesia also experienced the development of paradigm shift to follow global phenomenon. In the recent, practices bureaucracy public in Indonesia have led to the principles of the New Paradigm Public Service. This can be seen in some public policy that figured bottom-up, decision-making set in a hierarchical manner starting from the lowest level of structure like community, which later became the basis of the structure at the top. The pattern bottom-up showed a tendency that basically government considers community as a citizen or legal owner government is not as a customer or buyer (serve citizens, not customer).

The Citizen's Charter sees public services through the eyes of those who use them. For too long the provider has dominated and now it is the turn of the user. The principles of the Citizen's Charter, simple but tough, are increasingly accepted. They give more power to the citizens and more freedom to choose. The Charter is not a list of new principles of governance; instead, it has merely reiterated those norms which ideally should constitute the foundations of public administration. It is an attempt to bring back the basic values of public administration that have eroded due to various reasons. Citizen's perceptions about the working of the system form a vital part of our understanding of public administration (Lewis, 1993, pp. 316-326).

The benefits of citizen charter for the government as a service provider, as well as for the community as users of services, (Soeprapto, 2005), are: 
1) For the Government:

a) Make it easy to evaluate service performance. Because the implementation of public services is based on clear standards as stipulated in the document citizen's charters,

b) Help understand the needs and aspirations of citizens and stakeholders regarding the implementation of public services. Because the standard of service in citizen's charter is based on the real needs and aspirations of the community;

c) Increase public awareness that public services are not only the responsibility of the government but also the responsibility of all, including community members as service users.

2) For the community:

a) Providing guarantees that public services will be more responsive, meaning that citizen's charter provides public services based on the real needs of service users so that there is a match between the services provided and the needs of the community. Besides that citizen's charter guarantees transparency for the community, meaning that the community can easily know the aspects of service regarding the type, procedure, time, cost and method of service. And more accountable means that the public services provided can be accountable to the public as users of services;

b) Providing convenience to the public to access service information and the same time to control the implementation of services, because the community is directly involved in the process from the beginning to the end; Citizen's Model Development

c) Respect for the dignity and position of the community as sovereign citizens (communities as subjects). Although at the conceptual and normative level, the Citizen's Charter scheme is ideal, but its implementation is not without obstacles.

Explicitly the principles of the New Public Service in the implementation program reflected from the involvement of a variety group (element) who participate in the event. The role/main task participants is actively participate in decision-making process conference until the decisions. Likewise, in this research, the implementation of health program conceptually really reflects that direction, and proposed development planning from, for, and by citizens/community.

Bureaucracy public in Indonesia in Regional Autonomy era basically has been in a NPS paradigm, although it was still in formality. Process of drafting and implementation of Citizen's Charter in public services in line with a paradigm NPS with the principles especially: participatory, transparency and accountability. In practical terms, there must be more efforts to accommodate the role and raise awareness of the community that the community is the legal owner of the country so they also participate bear the responsibility in the process to welfare the people through active participation in various activities public administration.

Democratization in public service is manifestation of the good governance. The characteristics of good governance describe the ideal implementation of services public by the basic principles, transparency, participation, accountability, reponsif, democratic, effectiveness, efficiency and legal safeguards for human rights. So in the health sector, the patient is viewed not as customers, but it is their right as citizens to have a service. Thus, implementation in health service can open a wide space to citizens and stakeholders to work together to formulate a service provider services, a requirement, the procedure, cost, time, as well as standard satisfaction/quality of service that puts people in same position as a citizen that has dignity that must be respected by anyone. 


\section{Methods}

This research use a qualitative approach as a method to analyze the implementation Citizen's Charter in health services for the patients. Data Collection was done by observation, an interview, and documentation. The location of research was done in health clinic Perumnas, Arga Makmur City, North Bengkulu. As the first step researcher collecting data from origin informan those are Regional Officers that related to the policy, head of Puskesmas, Puskesmas officers, related officials at North Bengkulu District Health Office, and patients.

As the addition information the researcher also collecting data from key informant those are Head of Health Office, Head of Subdivision of Staffing, Sub-Section Head of Counseling and Medical Services, and Sub-Division Head of Programs and Community. Community informants are community leaders/nongovernmental organizations and school principals/teachers who are considered to have attention, knowledge and information about health services.

Researchers using SnowBall technic wich is a technic to ask one key infomant to tell another person who has more knowledge about the research until there is no new data variation collected (redundancy). Conclusion was made by arrangging naration so it could answered the focus problems in this research. This step showing and analyze all the data that found on the field and compared it to the basis theory applied. The conclusion then verified by all the informan as the validation of the data and conclusion of the research.

\section{Result and Discussion}

Results of the study showed that the policy of democratization and regional autonomy has not been able to give birth to Citizen's Charter in Public Service Area, especially The contract services in health service in the City Arga Makmur, Bengkulu Utara district. Realized the principles of the Citizen's
Charter in the puskesmas Perumnas Arga Makmur North Bengkulu district was found to have different characteristics with Citizen's Charter that happened in Java island in general. In North Bengkulu application of Citizen's Charter needs a polical will other than a strong support from local officials, the budget (General Revenue and Expenditure Budget/APBD), availability for infrastructure that adequate, commitment and Resources quality apparatus, the support of the society, and the need for a paradigm change the community for the formal treatment such as a health clinic, is also needed a personal leadership from the head of the community health center. In fact the community has accepted and is ready to perform Citizen's Charter that was born as a policy of democratisation and regional autonomy, but in reality it still needs the existence of an "personal leadership" to make innovation/creation program delegated to fill in public space. It turned out that health service in effort to improve the regions are still very much depends on figures or leadership in the region and has not been a part of the system will be continually, so if there is the most likely followed the succession to the change policy that interfere with the improvement of medical services policy continuity. Without the emergence initiatives of powerfulpersonal leadership, it could be confirmed the application Citizen's Charter in the area it is unlikely to happen.

Field reality show, the leadership of good personal in fact was not enough to be able to reform health services that is expected when faced with private interests or groups in certain areas, especially when it comes to self-interest or family local officials. Customs nepotism in the area is still coloring public service implementation in the region, although it has been published by Law No. 25/2009 on Public Service that is very strong commit a participation and democratisation in public services.

Democratisation policy and reginal autonomy, has growed and create creativity 
of organizer in health services, but not all community health clinic are able to respond innovation programs such as Citizen's Charter that was done by the community health center Perumnas. Reading skills and high education in the society has an effect to establish proceduresof Citizen'sCharter in health program. Number of people who are illiterate quite giving bad socialization in health care and efforts to encourage the society for treatment in the hospital/clinic. This is because socialization through mass media, pamphlets, posters, banners and others did not give the significant influence to society interest in the health program that carried out. In addition, more than education level of the people, the interest of the public is increased, trust in health experts such as medical doctor, the medical experts and drugs are more than generic.

The percentage of poor people were also has influnced the implementation of Citizen's Charter in the North Bengkulu. This can be seen from the point of view that appeared in the community on the assumption that treatment in formal treatment such as the Hospital/ Community Health Center is expensive and could not affordable for the poor. That affect interest the community, especially the poor to seek medical treatment to formal. As a result of interest lackness in the public becoming an obstacle in the formulation and agreement between the community as recipients of health service with health services provider so desire, complaints, and suggestions that felt by the public is not entirely will be fulfilled.

The contribution of this research for the world scientific studies in the implementation of public policy in efforts to provide Citizen's Charter in the Community Health Center Perumnas City Arga Makmur, Bengkulu Utara district has produced many more benefits to improve the public services. Both the local partners, government bureaucracies, as well as the user services in the city was agreed that there is a Citizen's Charter has benefits in three basic thing, which are (1) changes and cultural norms service of bureaucracy; (2) holding public service management is better, participatory, transparent and accountable; (3) and open space and chance of interaction between bureaucracy with the community.

For institutions public services, the model of Citizen's Charter has been giving guidance on what his institution improvements that must be done in public services. This is obtained especially when public consultation arrangement Citizen's Charter, in which public reported their perception on public services. Then after Citizen's Charter run, this model gives easy access to public service institutions to manage complain. From the activity monitoring and evaluation of the program that had been done succeed to find an improvement in the health services after implemented contract services, which can be seen from several indicators as follows:

1. The officials of the Community Health Center/Puskesmas are more friendly, being polite, do not smoke, and not doing other work when serving patients.

2. The officers provide service based on the schedule that had been agreed.

3. Service procedures are more clearly in line with what is stipulated in the contract service.

4. The performance of the officers is more clean and tidy according to the schedule.

5. User services can deliver criticism, complaints, and even demands if there is a complaint.

6. Relatively the service is according to the time promised.

Citizen's Charter has tried to introduce a changes norms or the new values service to bureaucracy and patients user services about the importance of ethics in service. Citizen's Charter gave bureaucracy and other stakeholders service a new form of cultural change (culture set) and mindset services that are 
much more humanist, and non-discriminative in organizing the public services. The officials bureaucracy have started to feel the importance a figure bureaucracy who appreciate and pay serious attention to the rights of user services.

Initiation to make Citizen's Charter in the community health center Perumnas gives an experience in bureaucracy to develop a management of public service that provides the opportunity of involvement in decisionmaking process policy. This activity has also make stakeholders services know many challenges and problems that occurred in the whole service process, especially when it comes to the cost, time, the procedure or mechanism, and so on. Thus, the effort to provide embrional Citizen's Charter in health service has encouraged the government's bureaucracy to implement the principles of transparency in organizing the public services. Bureaucracy is become accustomed to 'hear' the aspirations of stakeholders service and made bureaucracy feels they have a responsibility on service stakeholders in providing service. Citizen's Charter, with a 'Services' contract, which was formulated in it, has given a product accountability for new bureaucracy in providing service. Accountability service of bureaucracy now is aimed to stakeholders service as a whole.

For transparency and clarity of procedures service in the Community Health Center Perumnas can help and make it easier for patients in access to information, the time service fees, services, as well as product service, which developed from medical services as well as non-medical, the infrastructure to support services, and inspection mechanism through the rights and duties in applying penalties for users and service providers that are written in The contract Service.

Citizen's Charter has also given changes in bureaucracy health services to accept the criticism from stakeholders. Bureaucratic Officers together with society are trying to develop a partnership culture and collaborative to improve the performance of services to the people. The arrogance of Bureaucratic Officers are decreasing, and also stakeholders service no longer seemed reluctant to criticize the performance of bureaucratic officers in providing public service.

In the practice of public services there are not many government agencies implement the principles of the Citizen's Charter seriously. Provider of human resources who organized public services also have to be repaired, by using the system staffing more professional with the changes in Indonesia Statue No. 8 in 1974 becomes Indonesia Statue No. 43/1999 on Human Resources System of Civil. Human resources System apparently cannot be able to change public services in Indonesia, especially in the area that there is no "force" from the public. But experience proves that the idea of modern public services that base on mechanisms of Citizen's Charter or contract Service among government institutions with the elements service user is actually can be applied in Bengkulu and can increase public service performance especially in North Bengkulu District significantly.

Creativity and innovation in health services through the application Citizen's Charter as in North Bengkulu must be supported by the organizer or policy makers of public service so it could influence and give inspiration for positive changes in public service performance either in qualitative or quantitative.

\section{Conclusion}

The conclusion can be formulated is that the policies of democratization and regional autonomy have given birth to Citizen's Charter in Public Services in the Region, especially Service Contracts in health services in Arga Makmur City, North Bengkulu Regency. The adoption of the Citizen's Charter approach at once answered and justifies the question at the beginning of the study that the latest public 
service paradigm, the New Public Service paradigm, has given borth to a Citizen's Charter approach in health services.

Citizen's Charter gives bureaucracy and other service stakeholders a form of cultural change and a more humanistic, nondiscriminatory service mindset in the delivery of public services. The bureaucratic officials have begun to be able to feel the importance of a bureaucratic figure who respects and takes seriously the rights of citizens of service users. Likewise citizens, members of the Citizen's Charter Forum and other service stakeholders have begun to open their insights about the importance of controlling the quality of bureaucratic service performance so as not to violate basic rights of citizens in general. Bureaucratic officials also begin to recognize and familiarize themselves with the application of a 'culture of serving' in carrying out the tasks of service to the community. The serving culture introduced in Citizen's Charter is a culture that teaches respect for rights and obligations, both from the patient and service providers.

Citizen's Charter provides an experience with bureaucracy to develop a management of public service delivery that provides more tangible opportunities for engaging service stakeholders in the policy making process. The process of conducting surveys of service users, for example, has provided a new perspective among bureaucratic officials and members of the forum about the relevance of customer surveys for service responsiveness improvement. This activity also allows service stakeholders to find out various obstacles and problems that occur in the entire service process, especially regarding aspects of cost, time, procedures or mechanisms, and so on. Thus, Citizen's Charter has encouraged the government bureaucracy to be able to apply the principles of transparency in the delivery of public services.

\section{References}

Denhardt, J.V. \& Denhardt, R. B. (2003). The new public organizations: Serving, not steering. New York: M.E.Sharpe.

Denhardt,J.V.\& Denhardt, R.B. (2007). The new public service: Serving, not steering, expanded edition. NewYork: M.E. Sharpe.

De Vries, P. (1995). A review of some critical perspectives on development bureaucracy and policy. In G. Ferks and J.H. B. den Ouden (eds) In Search of the Midlle Ground: Essays on the Sociology of planned development. Wageningen: Agricultural University.

Dwiyanto, A. (2010). Manajemen pelayanan publik: Peduli, inklusif, dan kolaboratif. Yogyakarta: Gadjah Mada University Press.

Dwiyanto, A. (2005). Mewujudkan good governance melalui pelayanan publik. Yogyakarta: Gadjah Mada University Press.

Lewis, N. (1993). The Citizen's Charter and next steps: A new way of governing. The Political Quarterly, 64(3), 316-326. doi: 10.1111/j.1467923X.1993.tb00348.x

Maani, K. Dt. (2005). Citizen's Charter: Terobosan baru dalam penyelenggaraan layanan publik. Jurnal Tingkap, VI(2), 35-52.

Dwiyanto, A. (2005). Mewujudkan good governance melalui pelayanan publik. Yogyakarta: Gadjah Mada University Press.

Sedarmayanti. (2009). Reformasi administrasi publik, reformasi birokrasi dan kepemimpinan masa depan (mewujudkan pelayanan prima dan kepemerintahan yang baik). Bandung: Refika Aditama.

Soeprapto, R. (2005). Pengembangan model citizens charter dalam meningkatkan pelayanan publik di Indonesia. Jurnal Delegasi, 2, 123-150.

Stone, B. Administrative accountability in the 'westminster' democracies: towards a new conceptual framework. Governance, 8(4). doi: 10.1111/j.1468-0491.1995.tb00225.x 
Subijanto, B. (2007). Mekanisme pelayanan kemahasiswaan pada fakulas Ekonomi Universitas Sumatera Utara. Retrieved 2011, February 14 from http://www.sciencegate. ch/all-articles/detail?identifier $=60700063 \&$ title=Mekanisme+Pelayanan+Kemahasisw aan+Pada+Fakultas+Ekonomi+Universitas +Sumatera+Utara.

Syukri, A. F. (2010). Standar pelayanan publik pemda berdasarkan ISO 9001/IWA-4, Indonesian Quality Research Agency
(IQRA), Buaran, Serpong Tangerang Selatan, Banten.

Constitution No. 32/2004 Local Government. Constitution No. 8/1974 Civil Service System. Constitution No. 43/1999 Civil Service System. Constitution No. 25/2009 Public Service.

Wahyudi, K. (2009). Citizen Charter (Kontrak Pelayanan): Pola Kemitraan Strategi suntuk Mewujudkan Good Governance dalam Pelayanan Publik. Paper presented at Seminar Persadi in Indonesia, Pekanbaru. 